\title{
トリス $(\mathbf{1}, \mathbf{1 0}-フ ェ$ ェントロリン $)$ 鉄(II) キレート陽イオン によるサリチル酸の溶媒抽出吸光光度定量法*
}

\author{
山本勇麓, 熊丸 尚宏, 林康久, 大槌 光枝** \\ (1968 年 8 月 30 日受理)
}

\begin{abstract}
著者らは有機陰イオンを有色の金属キレート陽イオンとともに有機溶媒に抽出して，有機相における 金属キレートの吸光度を測定することによって当該陰イオンを比色定量する方法について一連の系統的 な研究を行なっている1) 8). 本報はその一環として, トリス (1,10-フェナントロリン)鉄(II) キレート 陽イオンを用いるサリチル酸の抽出吸光光度定量法を検討したものである.

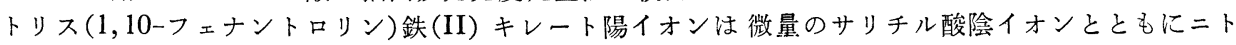
ロベンゼンに抽出され， $516 \mathrm{~m} \mu$ に極大吸収を示す. $\mathrm{pH}$ 5.5 9.5 の範囲において，トリス $(1,10-フ ェ$ ナントロリン)鉄 (II) キレート陽イオン濃度がサリチル酸に対して 50 倍モル以上であれば, 最大一定 の抽出妿得られ，また水相中のサリチル酸濃度が $8 \times 10^{-6} \sim 4 \times 10^{-5} \mathrm{M}$ の範囲でベール則に従うことが わかった。 共存物質として食品衛生法でその使用が許可されている合成保存料, 人工甘味料, サリチル 酸類縁化合物などについて，それらの影響を検討したところ，サッカリン，サイクラミン酸ナトリウム は正誤差を与えるが，デヒドロ酢酸，安息香酸，ソルビン酸などの保存料は 5〜30 倍モル存在しても影 響しないことを認めた。この方法を市販清酒中のサリチル酸の定量に応用した結果, 公定法の紫外吸収 法による定量結果と良好な一致を示した。
\end{abstract}

\section{1 緒言}

サリチル酸の定量法としては，保存料試験法として公 定法9)に採用されている鉄みょう䛃えによる比色法およ び紫外吸収スペクトル法があり, そのほか, 中和滴定 ${ }^{10)}$, ポーラログラフィー11) による定量法などが知られてい る.サリチル酸は防腐剂として指定食品に添加されてい るが，最近サリチル酸の人体に対する影響が重要視され ている現状にかんがみ，サリチル酸の新しい定量法の開 発を目的として，トリス (1,10-フェナントロリン) 鉄(II) キレート陽イオンを用いるサリチル酸の吸光光度定量法

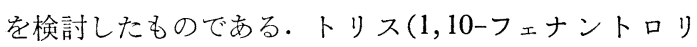
ン)鉄(II) キレート陽イオンは, 水相中の微量のサリチ ル酸の陰イオンと会合イオン対をつくり, 選択的に二ト ロベンゼン相に抽出され, かつ有機相の赤色（極大吸収 波長: $516 \mathrm{~m} \mu$ ) の強度が水相のサリチル酸の濃度に比例 することを見いだした．このような現象に基づいてサリ チル酸を比色定量する場合の基礎的条件を検討した結

* 金属キレート陽イオンによる陰イオンの 溶媒抽出 (第 33 報). 第 32 報は山本勇麓, 岡本信子, 峠 暎二：日化，89，399（1968)

** 広島大学理学部化学教室 : 広島市東千田町
果, 水相中のトリス $(1,10$-フェナントロリン)鉄(II) キ レート陽イオンの濃度をサリチル酸の 50 倍モル以上, pH 5.5〜9.5 に保って抽出すれば, $8 \times 10^{-6} \sim 4 \times 10^{-5} M$ の濃度範囲でサリチル酸を定量しうることを確認した。 次に，この方法を実試料に応用する試みとして，サリ チル酸が食品保存料として特に酒類および食酢について のみその使用が許可されている12)ことから，ここでは特 に清酒中に添加されている微量のサリチル酸の定量を行 ない, 公定法のうち広く採用されている紫外吸光光度法 と比較検討した. その結果, 両者による定量值は良好な 一致を示し, さらに本法のほうが感度が高いことがわか った。 またさきに, 著者らは本法と同様の原理に基づい たバトフェナントロリンー鉄(II) キレート陽イオンによ るサリチル酸の溶媒抽出吸光光度定量法を報告した1). バトフェナントロリンー鉄(II) キレート陽イオンによる 方法は本法に比較して感度がさらに高い点に特長がある が, 試薬が高価であり, 操作がやや煩雑であることを考 慮すると, 本法のほうが実用的であると考えられる。

\section{2 実験}

\section{$2 \cdot 1$ 装}

（1）分光光度計：日立製 139 型分光光度計，吸収セ 
ルはガラス製すり合わせキャップ付き $10 \mathrm{~mm}$ のものを 使用した。

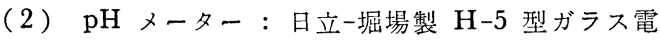
極 $\mathrm{pH}$ メーターを使用した。

（3）振り混ぜ器：イワキ製 KM 型を使用した.

\section{$2 \cdot 2$ 試 薬}

（1）サリチル酸標準溶液：エタノールー水混合溶媒 で再結晶して精製したサリチル酸 $\left(\mathrm{mp} 158 \sim 159^{\circ} \mathrm{C}\right)$ の $0.3488 \mathrm{~g}$ を水に溶かして $250 \mathrm{ml}$ とし $1.00 \times 10^{-2} M$ の 貯蔵液を調製した.なお，サリチル酸の希薄溶液は中性 またはアルカリ性で保存すると時間とともにその濃度が 減少する傾向を示すが, 一方, $\mathrm{pH} 2$ 以下の酸性溶液で は，てのような変化浔められないのでサリチル酸の貯 蔵液は硫酸酸性（pH 1.7）に保つこととした。実験に 際しては $2.0 \times 10^{-4} M$ にうすめて用いた。

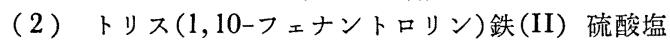

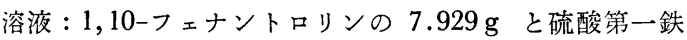
アンモニウム (モール塩) の $3.922 \mathrm{~g}$ を希硫酸に溶かし たのち, 水で $1000 \mathrm{ml}$ に希釈しトリス $(1,10$-フェナント ロリン)鉄 (II) として $1.0 \times 10^{-2} M$ の溶液（pH 2〜3） を調製した。

(3) 緩衝溶液 : $0.3 M$ リン酸二水素カリウム溶液と $0.3 M$ リン酸水素二ナトリウム溶液を適当に混合して調 製した。

（4）その他の試薬類：市販の特級品をそのまま用い た。

\section{3 標準操作}

分液漏斗に $0.3 M$ リン酸塩緩衝溶液 $(\mathrm{pH} \mathrm{6})$ の $5 \mathrm{ml}$, サリチル酸標準溶液 $\left(2.0 \times 10^{-4} M\right)$ の $5 \mathrm{ml}$, トリス $(1$, 10-フェナントロリン)鉄(II) 溶液 $\left(1.0 \times 10^{-2} M\right)$ の 8 $\mathrm{m} l$ を加え, 蒸留水で $25 \mathrm{~m} l$ に希勫したの方, ニトロベ ンゼンの $10 \mathrm{ml}$ を加え約 2 分間振り混ぜる. 分相のため 約 30 分間静置したのち, 有機相を分離し, 無水硫酸ナ トリウム $1 \mathrm{~g}$ で脱水し, 試薬ブランクまたはニトロベン ゼンを対照として， $516 \mathrm{~m} \mu$ の吸光度を測定する.

\section{3 結果と考察}

\section{1 吸収スペクトル}

操作 $2 \cdot 3$ に従って得られた有機相の吸収スペクトルを Fig. 1 に示す. 曲線 1 および 2 は, それぞれ水相中にサ リチル酸が存在する場合およびサリチル酸が存在しない 場合について，ニトロベンゼンを対照として測定したも のである. Fig. 1 からわかるように，このような条件で 浾色のトリス (1, 10-フェナントロリン)鉄(II) キレー ト陽イオンは微量のサリチル酸が存在するときはじめて ニトロベンゼンに抽出されるが，サリチル酸が存在しな いと，ほとえど抽出されないことが明らかである。

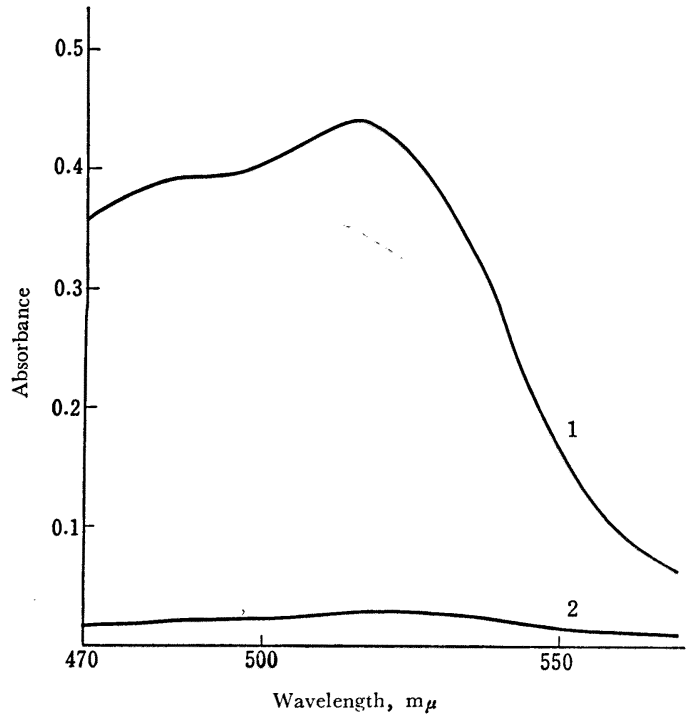

Fig. 1 Absorption spectra 1-Spectrum of the extract with salicylic acid,
Aqueous phase $: 25 \mathrm{ml}\left[\mathrm{Fe}(\mathrm{phen})_{3} 3.2 \times 10^{-3} \mathrm{M}\right.$, salicylic
acid $4.0 \times 10^{-5} \mathrm{M}$, buffer (pH 6$\left.) 0.06 \mathrm{M}\right]$, Organic
phase : $10 \mathrm{~m} l$ (Nitrobenzene); $2-$ Spectrum of the
extract without salicylic acid; Reference : Nitrobenzene

た，有機相における抽出種の極大吸収波長は $516 \mathrm{~m} \mu$ で あり，以後の実験では $516 \mathrm{~m} \mu$ を測定波長として用いる ことにした.

\section{2 抽出に及ぼす $\mathbf{p H}$ の影響}

2.3 の操作で水相の $\mathrm{pH}$ を種々変化させて, 抽出後 の有機相の吸光度を測定した. $\mathrm{pH}$ の調整は $0.3 M$ リ ン酸二水素カリウムーリン酸水素二ナトリウム 系緩衝溶 液を用い, 低い $\mathrm{pH}$ では硫酸, 高い $\mathrm{pH}$ では水酸化ナ トリウム溶液を併用した. Fig. 2 に示すように pH 5.5 〜9.5 の間で最大かつ一定の抽出が得られる.

一方, サリチル酸の $\mathrm{p} K_{1}$ は 2.98, $\mathrm{p} K_{2}$ は 13.61 で

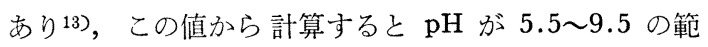
囲では, サリチル酸は 1 価の院イオンとして存在してい ることになる．このことから，この場合サリチル酸は 1

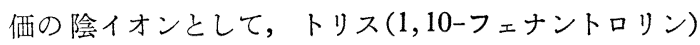
鉄(II) キレート陽イオンとイオン対を形成して抽出さ れると考えられる。

\section{3 トリス $(1,10$-フェナントロリン) 鉄 $(\mathrm{II})$ キレート 濃度の影響}

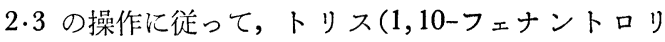
ン)鉄 (II) キレートの添加量を種々変えたときの抽出挙 


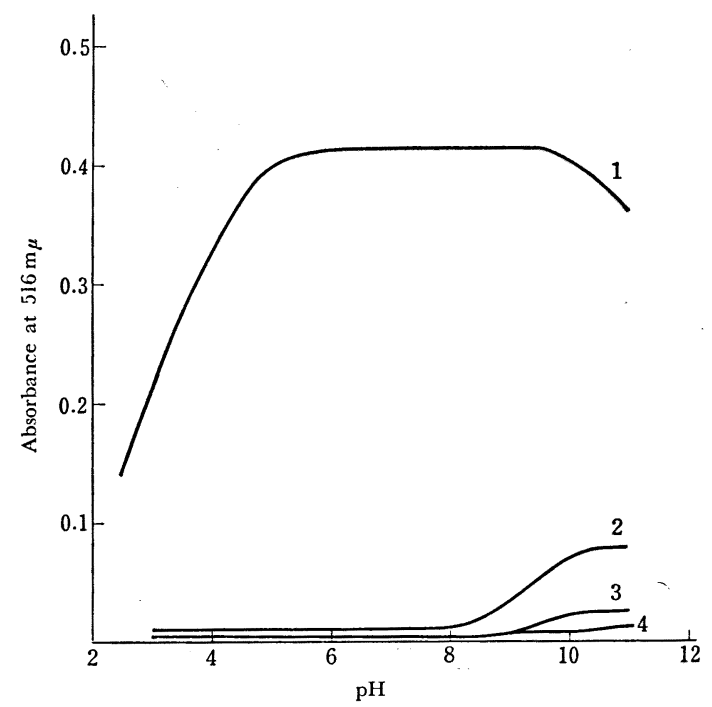

Fig. 2 Effect of $\mathrm{pH}$ on the extraction of salicylic acid and its homologues

$1:$ Salicylic acid; 2 : Benzoic acid; 3 : Phenol; 4 : $p$-Hydroxybenzoic acid; Concentration : $4.0 \times 10^{-5} \mathrm{M}$; Reference : Reagent blank

動を調べた. その結果を Fig. 3 亿示す.これより，ト リス (1,10-フェナントロリン)鉄(II) キレート溶液の濃 度が $2.0 \times 10^{-3} M$ 以上，すなわち，サリチル酸、に対し て 50 倍モル以上の濃度であれば一定の抽出が得られる

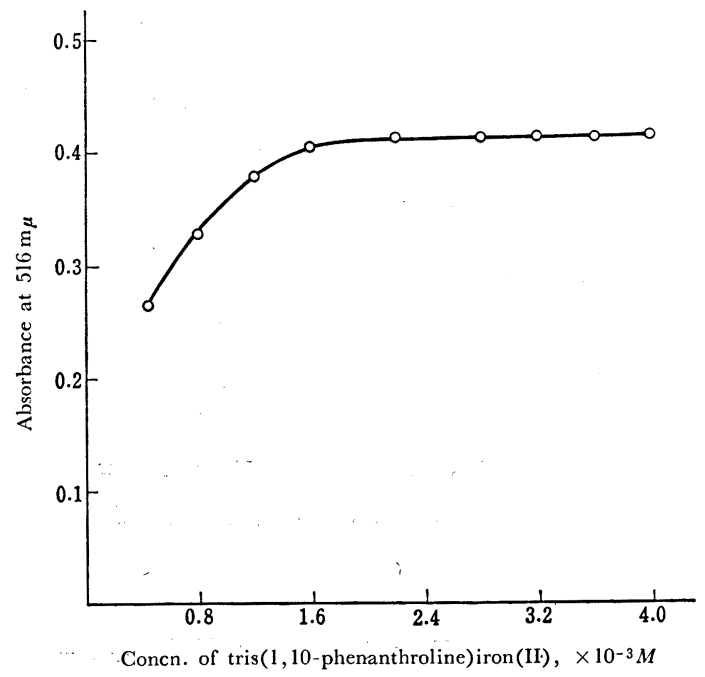

Fig. 3 Effect of tris (1,10-phenanthroline)iron(II) concentration

Concentration of salicylic acid : $4.0 \times 10^{-5} \mathrm{M}$; Reference : Reagent blank
ことがわかる。この実験ではトリス $(1,10$-フェナントロ

リン)鉄(II) キレート溶液の濃度を $3.2 \times 10^{-3} M$ に保 つことにした.

\section{4 振り混ぜ時間}

2.3 の操作において, 振り混ぜ時間について検討し た.その結果，1 分間以上の振り混ぜ時間で吸光度は最 大一定となり，抽出はきわめてす夕やかに平衡に達する ことを認めた．この実験においては便宜上，2分間振り 混ぜることにした。

\section{5 呈色の安定性}

2.3 の操作において，サリチル酸の濃度を $4.0 \times 10^{-5}$ $M$ および $2.0 \times 10^{-5} M$ に保って抽出を行ない，得られ た有機相の室温における 呈色の 経時变化を 調べたとこ ろ, 有機相の吸光度は抽出後少なくとも 3 時間はほとん ど一定であり, 呈色はかなり安定であることがわかっ た。

\section{6 検量線}

以上の諸条件を検討した結果から 2.3 の標準操作を定 めた. 2.3 の操作において, サリチル酸標準溶液の添加 量を变化させて試薬ブランク対照で $516 \mathrm{~m} \mu$ の吸光度を 測定する. その結果は Fig. 4 に示すように水相中のサ リチル酸の濃度が $8 \times 10^{-6} \sim 4 \times 10^{-5} M$ の範囲でベール 則を満足している.

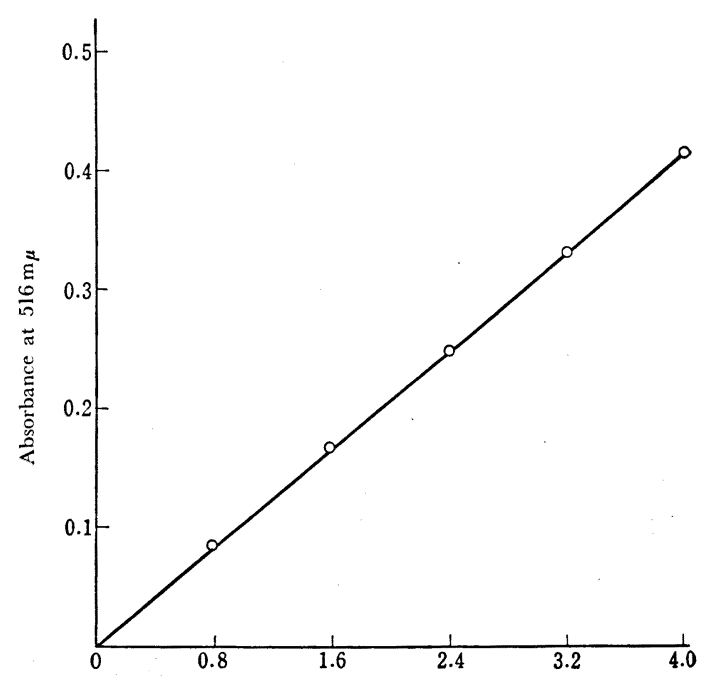

Concn. of salicylic acid in aqueous phase, $\times 10^{-5} \mathrm{M}$

Fig. 4 Calibration curve Reference : Reagent blank 
この標準操作に従って 8 回のくりかえし精度を求めた 結果, サリチル酸の濃度が $4.0 \times 10^{-5} M$ の水準で，す なわち, 平均吸光度 0.413 で標準偏差は $0.5 \%$ であっ た.また，抽出時の温度による影響も少なく $10 \sim 30^{\circ} \mathrm{C}$ の実験範囲では，試薬ブランクを対照とする場合注とん ど吸光度に変化はみられなかった。

\section{7 溶媒の選択}

$2 \cdot 3$ の標準操作において, サリチル 酸濃度を $4.0 \times$ $10^{-5} M$ に保ち, 抽出溶媒として, ニトロベンゼンのほ かにクロルベンゼン, ベンゼン, クロロホルム, 四塩化 炭素，1,2-ジクロルエタンなどの溶媒について，抽出の 挙動を観察した結果，ニトロベンゼン以外の溶媒にはほ とえど抽出されなかった、したがって, 本実験ではニト ロベンゼンを最適溶媒として用いることにした。

\section{8 抽出種の組成}

3.2 においても考察したように，この抽出において は，トリス $(1,10$-フェナントロリン)鉄(II) キレート陽 イオンとサリチル酸の 1 価の陰イオンが会合イオン対を 形成してニトロベンゼンに抽出されると考えられる.こ のことを確かめるために $\mathrm{pH} 6$ においてトリス $(1,10-フ$ ェナントロリン)鉄(II) 硫酸塩とサリチル酸の混合比を

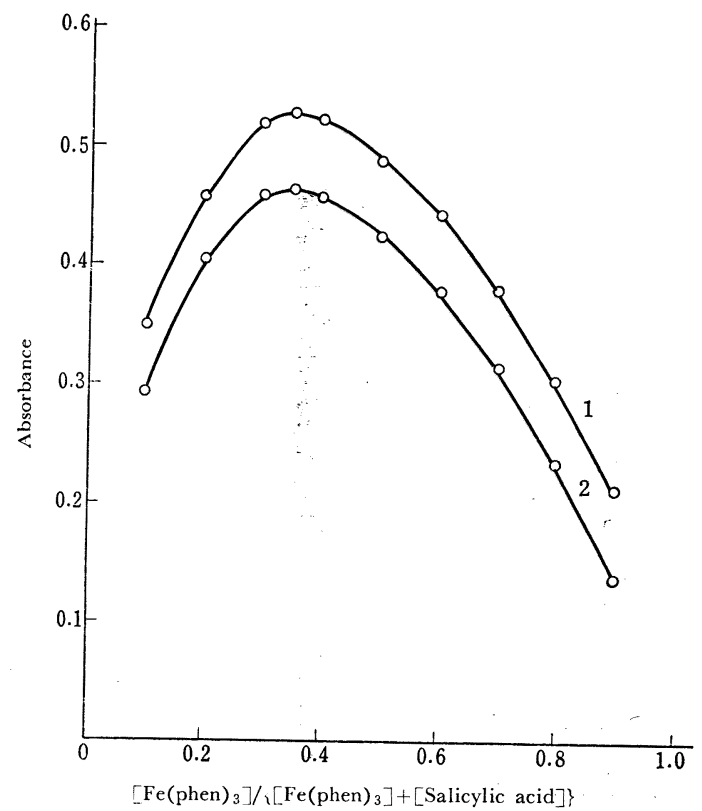

Fig. 5 Continuous variation plots at $\mathrm{pH} 6$ $1: 516 \mathrm{~m} \mu ; 2: 480 \mathrm{~m}_{\mu} ; \quad$ Total concentration : $1.2 \times$ $10^{-3} \mathrm{M} ;$ Reference : Reagent blank
種々変えて，連続変化法による検討を行なったと結 果を Fig. 5 に示す.

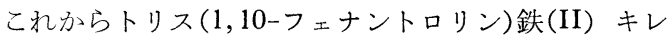
一ト陽イオンとサリテル酸の㓌イオンとのモル組成比 は 1:2 であることがわかる.したがって，サリチル酸 の解離種のうち 1 洒の陰イオンが抽出に関与すること が明らかであり, 抽出種の化学形は, $\left[\mathrm{Fe}(\mathrm{phen})_{3}{ }^{2+}\right]$. $\left[\mathrm{C}_{6} \mathrm{H}_{4}(\mathrm{OH}) \mathrm{COO}^{-}\right]_{2}$ と推定される.

\section{9 共存物質の影響}

2.3 の操作に従ってサリチル酸を定量する場合, 多量 のリン酸イオン, 硫酸イオン, ホウ酸イオンなどの無機 陰イオンが共存しても影響しないことは既報2 ${ }^{2)}$ )の場合 と同様である.ここでは特に食品衛生法で許可されてい る合成保存料, 人工甘味料, その他の食品添加物および サリチル酸類縁化合物が共存する場合について検討を行 なった・その結果を Table I に示す.

Table I Determination of salicylic acid in the presence of various substances

\begin{tabular}{lcc}
\hline \multicolumn{1}{c}{ Substance } & $\begin{array}{c}\text { Mole ratio } \\
\text { to SA }\end{array}$ & $\begin{array}{c}\text { Recovery of } \\
\text { SA (\%) }\end{array}$ \\
\hline Dehydroacetic acid & 5 & 102 \\
Potassium sorbate & 10 & 113 \\
Nitrofurazone & 30 & 106 \\
Benzoic acid & 1 & 100 \\
Phenol & 5 & 105 \\
p-Hydroxybenzoic acid & 10 & 102 \\
Saccharose & 10 & 103 \\
Dulcin & 500 & 101 \\
Sodium cyclamate & 10 & 108 \\
Saccharin sodium & 0.5 & 125 \\
Glycine & 0.1 & 115 \\
Sodium glutamate & 1000 & 118 \\
Sodium citrate & 1000 & 105 \\
Sodium chloride & 100 & 100 \\
Sodium bicarbonate & 50 & 116 \\
Potato starch & 50 & 110 \\
\hline
\end{tabular}

Salicylic acid (SA) : $4.0 \times 10^{-5} M$

クエン酸, グルタミン酸ナトリウム, でえ粉, グリシ ンなどはサリチル酸に対して 100〜1000 倍モル共存し ても影響は認められない. 一方, サイクラミン酸, サッ カリン酸はサリチル酸と同様にトリス $(1,10$-フェナント ロリン)鉄 (II) キレート陽イオンとともにニトロベンゼ ンに抽出され233) 正誤差を与える. 保存料としてのデヒ ドロ酢酸については同様にして定量できることをさきに 報告した4)。しかし，定量感度が低いことに加えて本法 では低い $\mathrm{pH}$ で抽出を行なうので 5 倍モル程度の共存は 
影響しないことがわかった、なお，そのほか ールについても検討したが，pH 10 以上でわずかに抽 出される程度であり, 本実験の $\mathrm{pH} 6$ にお敄る抽出で は全然妨害しないことがわかった。ささらに，ホルマり ン，ヘキサミン，メナジオンおよびエステル類などは陰 イオンを形成しにくいので，糖類などと同じょうに多量 共存しても障害しないものと考えられる。

一方，サリチル酸を工業的に製造守る場合，その試料 に注類縁化合物である安息香酸, フェノール, $p$-ヒドロ キシ安息香酸がきょう雑し，サリチル酸と同様に抽出さ 机妨害する抢それがある。そこで，この三者については 特に抽出の $\mathrm{pH}$ 変化を調べた。 その結果は Fig. 2 亿合 わせて示したように，これらの類縁化合物はサリチル酸 と同量程度共存しても $\mathrm{pH} 8$ 以下では活とえぞ抽出さ れざ，妨害しないことが明らかである。

\section{4 清酒中のサリチル酸の分析}

以上のような種々の基礎的条件を検討した結果，サリ チル酸の定量にじゅうぶえ利用できることがわかったの で，実試料への応用の 1 例として清酒市販品中のサリチ ル酸の定量を試みた。

\section{1 清酒中のサリチル酸の分離定量}

公定法9)ではサリチル酸をエーテル抽出によって分離 したのち，紫外法による定量法が規定されているので本 法を適用する前にまず公定法によって分離を行なった。

4.1.1 サリチル酸の分離 試料の $100 \mathrm{ml}$ を正確に とり，10\% 水酸化ナトリウム溶液を加えてアルカリ性 とし, これを約 $30 \mathrm{~m} l$ になるまで水浴上で蒸発濃縮し, アルコールを除去する. 次に蒸留水を加えて $100 \mathrm{ml}$ と したのち，そのうちの $50 \mathrm{ml}$ を分液漏斗にとり，液がア ルカリ性を呈するときは，10\% 塩酸溶液で中和したの ち, さらに $10 \%$ 塩酸溶液 $2 \mathrm{ml}$ を加え, $50 \mathrm{ml}$ のエー テルで 2 回抽出する.ついで，有機相を蒸発ざらに移 し，エーテルの大部分を留去したのち，自然に揮散させ 残留物をサリチル酸の定量に供試する。

4.1.2 公定法 (UV 法) による定量 4.1.1 で得 られたエーテル蒸発残留物をエチルアルコールに溶解し $200 \mathrm{~m} l$ とする. これから $25 \mathrm{ml}$ をとりアルコールで $100 \mathrm{~m} l$ に希釈して $305 \mathrm{~m} \mu$ 亿打ける吸光度を測定する. 別にサリチル酸を含まない清酒中にサリチル酸標準溶液 を加えて同様の操作によって得られた検量線を用いてサ リチル酸を定量する.

4.1.3 本法による定量 $4 \cdot 1 \cdot 1$ によって得られたエ 一テル蒸発残留物を少量の温湯汇溶かし, 蒸留水を加え
て $500 \mathrm{~m} l$ に希积与る。これから $5 \mathrm{~m} l$ をとり, 2.3 の 標準操作に従ってニトロベンゼン相の吸光度を測定す る・別にサリチル酸を含まない清酒中にサリチル酸標準 溶液を加え同様の操作によって得られた検量線ふらりり チル酸を定量する。

\section{2 定量結果}

本法ならびに公定法により 3 種類の市販清酒（1 級） 中のサリチル酸の定量を行なった結果を Table II に示 す。これより 3 社の市販品はいずれもサリチル酸の法定 添加限度 $0.25 \mathrm{~g} / l\left(1.81 \times 10^{-3} M\right)^{9)}$ の範囲内古るこ とがわかる。

本法による結果法紫外吸收法のとれと良好な一致を示 しているが，紫外吸收法に比べ感度が高く，したがって 試料採取量を少なくすることもでき，選択性もすぐれて いることなどが特長である。

Table II Determination of salicylic acid in Japanese Sake

\begin{tabular}{|c|c|c|}
\hline \multirow{2}{*}{ Maker } & \multicolumn{2}{|c|}{ Salicylic acid $(g / l)$} \\
\hline & Proposed method & Official (UV) method \\
\hline A & $\begin{array}{l}0.244 \\
0.242\end{array}$ & $\begin{array}{l}0.239 \\
0.242\end{array}$ \\
\hline $\mathrm{B}$ & $\begin{array}{l}0.138 \\
0.137\end{array}$ & $\begin{array}{l}0.135 \\
0.138\end{array}$ \\
\hline C & $\begin{array}{l}0.159 \\
0.156\end{array}$ & $\begin{array}{l}0.151 \\
0.152\end{array}$ \\
\hline
\end{tabular}

\section{交献}

1) 山本勇麓, 熊丸尚宏, 坪内正弘, 沖村一三: 本 誌, 16, 937 (1967).

2) Y. Yamamoto, T. Kumamaru, Y. Hayashi, T. Kobayashi, R. Tanaka: Chem. Pharm. Bull. (Tokyo), 15, 1437 (1967).

3) 山本勇麓, 熊丸尚宏, 林 康久, 山手万知子: 薬 誌, 88, 28 (1968).

4) 山本勇麓, 熊丸尚宏, 林康久, 登芳男：同 上, 87, 1346 (1967).

5) 山本勇麓, 烊本信子, 峠 暎二：本誌， 14, 343 (1965).

6) 小辻奎也，桜井俊之，山本勇麓：日化，86,519 (1965)

7) Y. Yamamoto, T. Kumamaru, Y. Uemura : Anal. Chim. Acta, 39, 51 (1967).

8) 山本勇麓, 熊丸尚宏, 林 康久, 山手万知子: 本 誌, 16, 1181 (1967).

9）厚生省編：“衛生検查指針 III 食品衛生検査指針 (II) [III] 保存料検査法”, (1963).

10）船久保英一：“有機化合物確認法”, 中巻, p. 24 (1954)，(養賢堂).

11) G. H. Hale : Anal. Chem., 26, 1078 (1954).

12)日本薬学会編: “衛生試験法注解”, p. 165(1956), (金原出版). 
13) M. Calvin, K. W. Wilson : J. Am. Chem. Soc, 67, 2003 (1945).

Spectrophotometric determination of salicylic acid by solvent extraction with tris $(1,10$-phenanthroline)iron(II) chelate cation. Yuroku YAMAмото, Takahiro Kumamaru, Yasuhisa Hayashi and Mitsue Отsuch (Department of Chemistry, Faculty of Science, Hiroshima University, Higashisenda-machi, Hiroshima-shi)

A new spectrophotometric method is proposed for the determination of salicylic acid. The method is based on solvent extraction of the ion-pair formed between tris(1, 10-phenanthroline)iron(II) and the anion of salicylic acid into nitrobenzene.

The color intensity of the organic phase $(516 \mathrm{~m} \mu)$ is proportional to the initial amount of the salicylic acid in aqueous phase.

The constant extraction is obtained when the cationic metal chelate concentration is $3.2 \times 10^{-3} \mathrm{M}$ in the aqueous solution buffered at $\mathrm{pH} 5.5$ to 9.5 .

The calibration curve is constructed as follows.

To $5 \mathrm{ml}$ of $0.3 \mathrm{M}$ phosphate buffer solution ( $\mathrm{pH}$ 6) and $8 \mathrm{ml}$ of tris $(1,10$-phenanthroline)iron(II) solution $\left(1.0 \times 10^{-2} M\right)$ are added varying amounts of the standard salicylic acid solution $\left(2.0 \times 10^{-4} M, 0 \sim 5 \mathrm{ml}\right)$. It is diluted to $25 \mathrm{ml}$ with water, and is shaken for $2 \mathrm{~min}$. with $10 \mathrm{ml}$ of nitrobenzene. The absorbance of the organic phase is measured at $516 \mathrm{~m} \mu$ against the reagent blank.

A linear relationship is obtained over the range of $8 \times$ $10^{-6}$ to $4 \times 10^{-5} M$ of salicylic acid in aqueous solution.

The effect of diverse organic compounds such as preservatives, sweetening agents and others on this method was investigated.

The proposed method was applied to the determination of salicylic acid in commercial Japanese Sake and the results were in good agreement with those by official UV method.

(Received Aug. 30, 1968)

\title{
ネオクプロイン-銅(I) とのイオン対抽出による硝酸イオンの 間接原子吸光分析法*
}

\author{
山本 勇麓, 熊丸 尚宏, 林康久, 大谷 譲** \\ (1968 年 8 月 30 日受理)
}

\begin{abstract}
原子吸光分析法の新しい応用を目的として，金属キレートを用いる溶媒抽出法を併用する硝酸イオン の定量法を検討した。水溶液中に微量の硝酸イオンが存在するとき，ネオクプロインー銅(I) キレート 陽イオンは硝酸イオンとともに選択的にメチルイソブチルケトンに抽出され，さらにその有機相を空 気ーアセチレン炎に噴霧し，3247 $\AA$ の銅共鳴線を用いる原子吸光分析によって銅濃度を定量すれば，間 接的に硝酸イオンの定量が可能であることを見いだした。基礎的諸条件を検討した結果，pH $3.5 〜 5.5$ のもとで抽出を行なえば, 硝酸イオンの濃度は $10^{-5} \sim 7 \times 10^{-5} M$ の範囲で有機相の銅の吸光度と直線 関係を示すことがわかった。また, 共存イオンの影響は, 硫酸イオン, リン酸イオンは硝酸イオンに対 して 1000 倍モル程度, 炭酸イオンは 100 倍モル程度, 覀硫酸イオンは 10 倍モル程度共存してもほ とえどさしつかえなく, また, 塩素イオンやケイ酸イオンは等モル程度共存しても影響しなかった。し かし，チオシアン，過塩素酸イオンはかなりの正誤差を示した。
\end{abstract}

\section{1 緒 言}

原子吸光分析法は 1955 年 Walsh によって開発され て以来，主として金属元素の定量手段として多方面で活

*金属キレート陽イオンによる陰イオンの溶媒抽出 (第 38 報). 第 37 報は T. Kumamaru : Bull. Chem. Soc. Japan, 42, No. 4 (1969), 印刷中

-**広島大学理学部化学教室 : 広島市東千田町
用されるに至っているが，この方法の制約の一つは定量 しようとする元素と同じ元素からなる光源が必要である ということであり, 非金属元素ではホウ素, ケイ素, 七 素，セレン，テルルのように定量されるようになったも のもあるが，なお多くの非金属元素に対しては本法を直 接適用できないのが現状である.本研究はこのような原 子吸光分析法を無機および有機陰イオンへの適用にまで 抬大する試みの一環として, 硝酸イオンの定量法を検討 